\title{
Morphological and Biochemical Changes During Muskmelon (Cucumis melo var. Tibish) Fruit Maturation
}

\author{
Benoît Bargui Koubala, 2, *, Gabriel Bassang'na', Beda Marcel Yapo ${ }^{3}$, Raihanatou Raihanatou ${ }^{1}$ \\ ${ }^{1}$ Department of Life and Earth Sciences, Higher Teachers' Training College, University of Maroua, Maroua, Cameroon \\ ${ }^{2}$ Department of Chemistry, Faculty of Science, University of Maroua, Maroua, Cameroon \\ ${ }^{3}$ Subunit of Pedagogy in Biochemistry and Microbiology, Unit of Training and Research in Agroforestry, University of Jean Lorougnon \\ Guédé, Daloa, Ivory Coast
}

Email address:

bkoubala@yahoo.fr (B. B. Koubala)

\section{To cite this article:}

Benoît Bargui Koubala, Gabriel Bassang'na, Beda Marcel Yapo, Raihanatou Raihanatou. Morphological and Biochemical Changes During Muskmelon (Cucumis melo var. Tibish) Fruit Maturation. Journal of Food and Nutrition Sciences. Vol. 4, No. 1, 2016, pp. 18-28.

doi: $10.11648 /$ j.jfns.20160401.14

\begin{abstract}
Muskmelon (Cucumis melo) is a vegetable much appreciated by the Cameroonian population. The aim of this study was to investigate the effect of development stage on morphological and physicochemical characteristics of the fruit. These parameters were studied from the third to the seventh week after fruit set. The average weight, fruit size and proportions of the different fractions (peel, mesocarp and endocarp) were evaluated. Some physicochemical and antioxidant properties were also determined. Results showed that morphological parameters increased significantly $(p<0.05)$ during the development of the fruit of Cucumis melo. From the third to the seventh week after fruit set, the average weight varied from 105 to $404 \mathrm{~g}$. During the maturation of fruit, the weight of mesocarp was higher than that of endocarp. The studied physicochemical parameters, varied from a fruit fraction to another and also depended on the development stage. Results showed that the weight ratio of mesocarp (44-42\%) decreased meanwhile that of endocarp (41-44\%) increased down the growth. During the maturation of fruit, the proteins content of peels decreased from 1.7 to $0.4 \mathrm{mg} / \mathrm{g}$, while that of mesocarp and endocarp increased from 0.14 to $0.48 \mathrm{mg} / \mathrm{g}$ and from 1.38 to 4.26 , respectively. At stage 1 of development, the peels were two times richer in vitamin $\mathrm{C}(14.9 \mu \mathrm{g} / \mathrm{g})$ than the other fruit fractions (4.17-8.38). However, from stage 2 to stage 5 (full maturation), the mesocarp and endocarp appeared by far richer. The minerals requirements can be satisfy by the mesocarp or endocarp of Cucumis melo fruit harvested at five week after fruit set (stage 3). However, antioxidant capacity, carbohydrates, proteins and vitamin $\mathrm{C}$ are high in the fruit at stage 4 or 5.
\end{abstract}

Keywords: Cucumis melo Fruit, Growing Stage, Morphological Parameters, Physicochemical Properties

\section{Introduction}

Melon (Cucumis melo), which belongs to the family of Cucurbitaceae, is a creeping and / or climbing herb with nodes from which emanate filamentous organs called tendrils $[1,2]$. The fruit of Cucumis melo has been reported to be rich in antioxidants, especially vitamins ( $\mathrm{C}$ and $\mathrm{E}$ ) and flavonoids $[3,4]$. Therefore, increasing the consumption of this fruit may reduce the risk of various free radical-induced diseases such as cancer, cardiovascular and cerebrovascular diseases $[5,6]$. They are many varieties of $C$. melo [7], which fruits differ in morphological and biochemical characteristics. The concentration of sugars and aroma are the two most important factors in the qualities perceived by consumers [8].
Like pumpkins, Cucumis melo var. Tibish can provide proteins, sugars, vitamin $\mathrm{C}$ and minerals needed for human diets [9].

In the Far North of Cameroon, the Tibish variety represents an important income for farmers. This melon fruit is widely and regularly presented on the local markets of cities, unlike other fruits that are periodically sold. However, most local people are not aware of the nutritional qualities of this fruit, and therefore its level of consumption is still rather low. Also, the fresh vegetable parts of this melon fruit does not receive much consideration, because for many people, the major concern is to intake enough caloric foods. However, each serving portion of this vegetable, at different stages of maturity, has a specific proximate composition. Peels can, for example, be used as a source of dietary fiber [10]. The 
mesocarp can be used as a source of carbohydrates, minerals and vitamins [3]. The endocarp, with its seeds, can be good source of lipids $[11,12]$. The economic potential of melon Tibish would largely be untapped due to the poor market quality of the fruit and the consumers unawareness of its nutritional value.

The main objective of this study was to add value to Cucumis melo var. Tibish by assessing changes (which occurred) in morphological and physicochemical features during the fruit development.

\section{Material and Methods}

\subsection{Sampling and Morphometric Characterization}

The experimental work was carried out in a private orchard in the town of Maroua (Cameroon) during the raining season (june-september). Cucumis melo fruits of Tibish variety, were collected at various stages of fruit development. The first stage of development was three weeks after anthesis and the other stages (2,3,4 and 5) were determined at weekly intervals. The fifth stage was the last ripening stage where the skin of the fruit appeared yellow.

About thirty fruits per stage were weighed to determine the average weight. Their sizes (length and diameter) were also measured using a caliper. The fruits were washed and thoroughly cleaned before peeling them with a stainless steel knife. The different physical parts (peels, mesocarp and endocarp) of the fruits were isolated and weighed to determine their weight ratio. The peels, mesocarp and endocarp of the fruits were chopped into pieces of about 1 $\mathrm{cm} \times \mathrm{cm}$ and dried in an air-circulated oven at $50^{\circ} \mathrm{C}$. Dried samples were then blended and passed through mesh of 0.25 $\mu \mathrm{m}$ screen to obtain homogenized powders. The latter were stored under airless and moisture-free conditions pending analysis.

\subsection{Physicochemical Analysis}

The dry matter content of the different fractions of Cucumis melo fruit and the ash content of the dried sample were determined using the standard AOAC [13] method. Aliquots of the juice of fresh samples was taken [14] and their $\mathrm{pH}$ was measured using a calibrated pH meter (HI 8424 Microcomputer Hanna instruments). The bulk density of peels, mesocarp and endocarp was determined by the volume $(\mathrm{mL})$ occupied by the sample tapped in a measuring cylinder per gram of dried sample.

The Ninhydrin colorimetric method [15] was used to determine the free amino acids content of the samples. One hundred milligrams $(100 \mathrm{mg})$ of dried samples were placed in a beaker containing $10 \mathrm{~mL}$ of distilled water and stirred at $4^{\circ} \mathrm{C}$ for $24 \mathrm{~h}$ and filtered. The total proteins content of the sample solution obtained was determined using an acetyl acetone/formaldehyde method [16]. Samples were first mineralized using Kjeldahl method [17]. The nitrogen content of the mineralisates was evaluated after reacting ammoniac $\left(\mathrm{NH}_{3}\right)$ with acetyl acetone/formaldehyde. The absorbance of the resulting yellow complex (3, 5-diacetyl-1, 4-dihydrolutidin) was colorimetrically measured at $412 \mathrm{~nm}$. A conversion factor of 6.25 was used to determine the proteins content of the fruit fractions.

Free sugars and carbohydrates content of peels, mesocarp and endocarp were colorimetrically determined by the orcinol method [18]. Free sugars were obtained after stirring dried samples with $80 \%(\mathrm{v} / \mathrm{v})$ ethanol. As regards the evaluation of the total carbohydrates content, polysaccharides in samples were pre-hydrolyzed with $13 \mathrm{M} \mathrm{H}_{2} \mathrm{SO}_{4}(30 \mathrm{~min}$, $25^{\circ} \mathrm{C}$ ), which was diluted to $2 \mathrm{M} \mathrm{H}_{2} \mathrm{SO}_{4}$ with distilled water, and further hydrolyzed at $100^{\circ} \mathrm{C}$ for $2 \mathrm{~h}$ in order to release corresponding monomers [19]. The crude lipids content of the samples was determined according to the standard AOAC [13] method.

The crude fiber content of samples was determined according to the standard AOAC [13] method. Dried samples were hydrolyzed with $0.26 \mathrm{~N} \mathrm{H}_{2} \mathrm{SO}_{4}\left(100^{\circ} \mathrm{C}, 30 \mathrm{~min}\right)$ and washed three times with distilled water. The acid hydrolyzates were further hydrolyzed with $0.23 \mathrm{~N} \mathrm{KOH}$ and washed successively with distilled water, ethanol and acetone. The residue was dried and incinerated in a muffle furnace $\left(550^{\circ} \mathrm{C}\right.$ for 6 hour to remove the ash. The iodine method of Jarvis and Walker [20] was used to determine the starch content of the Cucumis melo fruit fractions. Samples were pretreated with $1 \mathrm{M} \mathrm{KOH}$ at room temperature followed by $1 \mathrm{~N} \mathrm{HCl}$ at room temperature and finally treated in boiling water for $15 \mathrm{~min}$. The slurry obtained was centrifuged (9000 g) and the supernatant was used for analysis.

\subsection{Evaluation of Antioxidant and Hydration Capacities}

About $0.5 \mathrm{~g}$ of dried sample was put in a beaker containing $10 \mathrm{~mL}$ of distilled water. This was stirred for $1 \mathrm{~min}$ and equilibrated for $1 \mathrm{~h}$ before filtering. The wet sample was weighed. The water absorption capacity was measured as the quantity of water absorbed at equilibrium per gram of dried sample. Swelling kinetics was performed after Kuniak \& Marchessault [21]. Briefly, $0.5 \mathrm{f}$ of dried sample was put in a $10 \mathrm{ml}$ measuring cylinder and the volume occupied was recorded. About $8 \mathrm{~mL}$ of distilled water was then added and mixed. The increase of the sample volume with time was recorded until equilibrium.

Vitamin C was extracted by stirring $100 \mathrm{mg}$ of samples in $25 \mathrm{~mL}$ of $0.5 \%$ oxalic acid solution. The extract was clarified and brought to $50 \mathrm{~mL}$ with $0.5 \%$ oxalic acid solution and analyzed against a standard solution of vitamin $\mathrm{C}$ using the N-Bromosuccinimid titrimetric method [22].

Methanolic extracts of sample were analyzed for their total phenolic content, total antioxidant capacity and DPPH radical-scavenging activity. The total phenolic content was measured by the Folin-Ciocalteu method as reported by Singleton et al. [23]. Results were expressed in term of milligram of gallic acid equivalent (GAE) per gram of sample. The total antioxidant capacity was evaluated by the ferric reducing antioxidant potential (FRAP) of the fruit fractions according to their ability to reduce Fe (III)-2, 4, 6Tri(2-pyridyl)-s-triazine (TPTZ) complex to Fe (II)-TPTZ at 
$593 \mathrm{~nm}$ [24]. The free radical scavenging activity (FRSA) of the samples were determined by using DPPH (2, 2-diphenyl1-picrylhydrazyl) free radical as performed by Sun et al. [25]. Results of FRAP and FRSA were expressed in term of micromole equivalent Trolox per gram of sample.

\subsection{Statistical Analysis}

All analyses were performed in three independent runs and results were given as the means \pm standard deviations. All the data obtained were statistically appraised by one-way ANOVA and means of various treatments were considered to be significantly different at p-value of 0.05 by KeulsNewman test. Correlation between total phenolic compounds, antioxidant activities and vitamin $\mathrm{C}$ content of $C$. melo fruit fractions was studied by Pearson correlations $(\mathrm{p}<0.05)$.

\section{Results and Discussion}

\subsection{Influence of Developing Stage on the Growth Parameters of Melon (Cucumis melo var. tibish) Fruit}

\subsubsection{Fruits Size}

Equatorial and polar diameters of Cucumis melo (var. tibish) fruit significantly $(p<0.05)$ increased during growth (Table 1). The polar diameter gradually increased from 8.87 to $10.89 \mathrm{~cm}$ from the third to the sixth week after fruit set, followed by a significant increase $(p<0.05)$ at the seventh week $(13.83 \mathrm{~cm})$. Ahmed [26] has reported a much higher increase in the polar diameter of Galia melon (up to 35 - 37 $\mathrm{cm}$ ). This difference may be attributed to climatic and soil or varietal variations. Throughout the growth, the equatorial diameter (from 5.87 to $8.18 \mathrm{~cm}$ ) was lower than the polar diameter fruit. However, unlike the polar diameter, equatorial diameter slightly varied during fruit maturation. This increase in fruit size may be related to the classic form of the evolution of biological variables during growth [27]. Similar findings were reported by Ahmed [26] on Cucumis melo of the Galia cultivar. Variations observed at the seventh week after fruit set suggested that at this stage the optimum maturity was reached.

\subsubsection{Mean Weight}

Table 1 shows that the weight of fruits varied significantly $(p<0.05)$ from the third $(105 \mathrm{~g})$ to the seventh week (404 g) after fruit set. The weight increase may be due to accumulation of plant reserves in the fruit. Villanueva et al. [28] have made similar observations with Piel de Sapo (955-2371 g) and Rochet (1039-2199 g) melon varieties. However, the average weights of the latter were higher, compared to that of the Tibish melon variety, probably due to difference in cultivars and growing location.

\subsubsection{Weight Proportion and Bulk Density}

The weight of peels represented only about $12 \%$ of the fruit total weight while those of the endocarp (39-46\%) and the mesocarp (42-49\%) were greater. During the growth of the fruit, the weight proportion of melon peels does not evolve linearly. That of mesocarp decreased with the maturation stage of fruit whereas that of the endocarp increased (Table 1). These differences observed, depending on the maturation stage would be due to accumulation of reserve nutrients and water in those portions of the fruit.

The bulk density of the fruit fractions varied from 0.22 to $0.52 \mathrm{~g} / \mathrm{mL}$ (Table 1). These values decrease during the fruit maturation. However, a greater decrease occurred in mesocarp and endocarp, which appeared to be denser than the peels. The low density of the peels may be due to their high fiber content. Further, the increase in the crude lipids content of these fractions was in line with the decrease of their density.

Table 1. Effect of the maturity stage on the size, mass characteristics, pH and dry matter content of Cucumus melo fruit fractions (peel, mesocarp and endocarp). Bulk density is given in $g$ of dry powder per $m L$.

\begin{tabular}{|c|c|c|c|c|c|c|}
\hline \multirow{2}{*}{ Characteristics } & & \multicolumn{5}{|c|}{ Stage of maturity } \\
\hline & & S 1 & S 2 & S 3 & S 4 & S 5 \\
\hline Average weight $* *(\mathrm{~g})$ & & $105.44 \pm 11.65^{\mathrm{d}}$ & $189.59 \pm 16.29^{c}$ & $285.38 \pm 17.67^{b}$ & $391.74 \pm 25.42^{\mathrm{a}}$ & $404.44 \pm 15.02^{\mathrm{a}}$ \\
\hline Polar diameter $* *(\mathrm{Cm})$ & & $8.87 \pm 0.20^{\mathrm{c}}$ & $9.03 \pm 0.19^{c}$ & $10.30 \pm 0.24^{\mathrm{b}}$ & $10.89 \pm 0.17^{b}$ & $13.83 \pm 0.21^{\mathrm{a}}$ \\
\hline Equatorial diameter $* *(\mathrm{Cm})$ & & $5.87 \pm 0.12^{\mathrm{d}}$ & $7.04 \pm 0.18^{\mathrm{c}}$ & $7.32 \pm 0.20^{\mathrm{bc}}$ & $7.66 \pm 0.16^{\mathrm{b}}$ & $8.18 \pm 0.22^{\mathrm{a}}$ \\
\hline \multirow{3}{*}{ Massic ratio $*(\%)$} & $P e$ & $12.62 \pm 0.59^{\mathrm{a}}$ & $12.24 \pm 0.41^{\mathrm{a}}$ & $11.61 \pm 0.33^{b}$ & $11.51 \pm 0.41^{\mathrm{b}}$ & $12.60 \pm 0.38^{\mathrm{a}}$ \\
\hline & $M e$ & $44.16 \pm 0.43^{\mathrm{c}}$ & $47.83 \pm 0.38^{\mathrm{b}}$ & $48.72 \pm 0.29^{\mathrm{a}}$ & $43.54 \pm 0.35^{\mathrm{c}}$ & $42.04 \pm 0.42^{\mathrm{d}}$ \\
\hline & $E n$ & $41.40 \pm 0.34^{\mathrm{b}}$ & $39.45 \pm 0.39^{c}$ & $38.80 \pm 0.28^{c}$ & $45.73 \pm 0.45^{\mathrm{a}}$ & $44.27 \pm 0.49^{\mathrm{a}}$ \\
\hline \multirow{3}{*}{ Bulk density * $(\mathrm{g} / \mathrm{mL})$} & $P e$ & $0.44 \pm 0.03^{\mathrm{a}}$ & $0.33 \pm 0.04^{\mathrm{b}}$ & $0.33 \pm 0.05^{\mathrm{b}}$ & $0.38 \pm 0.03^{\mathrm{a}}$ & $0.37 \pm 0.04^{\mathrm{ab}}$ \\
\hline & $M e$ & $0.51 \pm 0.05^{\mathrm{a}}$ & $0.47 \pm 0.06^{\mathrm{ab}}$ & $0.45 \pm 0.04^{\mathrm{ab}}$ & $0.44 \pm 0.03^{b}$ & $0.29 \pm 0.03^{\mathrm{c}}$ \\
\hline & $E n$ & $0.52 \pm 0.04^{\mathrm{a}}$ & $0.44 \pm 0.05^{\mathrm{b}}$ & $0.45 \pm 0.05^{\mathrm{b}}$ & $0.45 \pm 0.06^{\mathrm{b}}$ & $0.29 \pm 0.04^{\mathrm{c}}$ \\
\hline \multirow{3}{*}{ Dry matter content $*(\%)$} & $P e$ & $8.36 \pm 0.06^{\mathrm{c}}$ & $8.18 \pm 0.18^{\mathrm{c}}$ & $8.37 \pm 0.14^{\mathrm{c}}$ & $9.94 \pm 0.20^{b}$ & $11.49 \pm 0.10^{\mathrm{a}}$ \\
\hline & $M e$ & $6.30 \pm 0.12^{\mathrm{a}}$ & $5.53 \pm 0.06^{\mathrm{d}}$ & $5.78 \pm 0.09^{c}$ & $5.78 \pm 0.04^{\mathrm{c}}$ & $6.01 \pm 0.05^{\mathrm{b}}$ \\
\hline & $E n$ & $8.70 \pm 0.07^{b}$ & $6.89 \pm 0.13^{\mathrm{d}}$ & $9.77 \pm 0.12^{\mathrm{a}}$ & $6.96 \pm 0.13^{\mathrm{d}}$ & $7.88 \pm 0.15^{\mathrm{c}}$ \\
\hline \multirow{3}{*}{$\mathrm{pH} *$} & $P e$ & $5.29 \pm 0.09^{\mathrm{a}}$ & $5.05 \pm 0.06^{b}$ & $5.20 \pm 0.08^{\mathrm{ab}}$ & $4.67 \pm 0.07^{\mathrm{c}}$ & $4.65 \pm 0.02^{\mathrm{c}}$ \\
\hline & $M e$ & $4.86 \pm 0.05^{b}$ & $4.93 \pm 0.03^{b}$ & $5.03 \pm 0.03^{\mathrm{a}}$ & $4.86 \pm 0.05^{\mathrm{b}}$ & $4.88 \pm 0.02^{b}$ \\
\hline & $E n$ & $4.27 \pm 0.03^{\mathrm{b}}$ & $5.01 \pm 0.03^{b}$ & $5.26 \pm 0.04^{\mathrm{a}}$ & $4.99 \pm 0.03^{\mathrm{b}}$ & $4.95 \pm 0.05^{\mathrm{b}}$ \\
\hline
\end{tabular}

*Mean values from triplicate or **thirty measurements \pm standard deviation

Values in the same line followed by different superscripts are significantly different $(\mathrm{p}<0.05)$. The stages are determinate three (S1), four (S2), five (S3), six (S4) and seven (S5) weeks after fruit development. $\mathrm{Pe}=$ Peel; $\mathrm{Me}=$ Mecocarp; $\mathrm{En}=$ Endocarp 


\subsection{Effect of the Maturity Stage on the Physicochemical Parameters of Peels, Mesocarp and Endocarp from Melon (Cucumis melo) of Tibish Variety}

\subsubsection{Dry Matter Content and $\mathrm{pH}$ of the Physical Parts of Melon Fruit}

The results of dry matter and $\mathrm{pH}$ analysis are shown in Table 1. The dry matter content of melon peels (8.18 to $11.49 \%$ ) increased throughout fruit maturation. However, those of the endocarp and mesocarp decreased (stage 2 and stage 4) and increased (stage 3) during the fruit development. The most abundant fraction (mesocarp) of the fruit had low dry matter content (Table 1). Tibish melon peels exhibited the highest dry matter content. These variations in the dry matter content have also been observed by Bernadac et al. [29] with Cucumis melo L. var. maestro.

The $\mathrm{pH}$ of the various fruit fractions varied from 4.27 to 5.29. Parveen et al. [30] have also noted similar variations in $\mathrm{pH}$ (5.38 to 5.58) with Ravi melon variety. However, Beaulieu et al. [31] have reported a slightly higher $\mathrm{pH}$ value (6.79) with Cantaloupe variety. According to Bianchi et al. [32], the $\mathrm{pH}$ of melon significant varies from 5.2 to 6.5 depending on the cultivar used. The $\mathrm{pH}$ of the melon peels of tibish decreased while that of the endocarp increased with the fruit maturation. By contrast, with the mesocarp, a $\mathrm{pH}$ peak was observed at the fifth week (stage 3) after fruit set. These variations could be due to the synthesis (or degradation) of organic acids during the fruit maturation. Ozawa et al. [33] have shown that pectins from mature berries can be free from the cell wall and bind to polyphenols, thereby causing a decrease in acidity and increase in $\mathrm{pH}$.

\subsubsection{Ash Content}

The ash content of peels ranged from 13.53 to $18.95 \mathrm{mg}$ / g (fresh weight). Much lower values were observed for the mesocarp (3.62 to $5.47 \mathrm{mg} / \mathrm{g}$ ) and endocarp (5.76 to $11.74 \mathrm{mg} / \mathrm{g}$ ) (Figure 1). During the fruit maturation, it was noted that the ash content of melon peels significantly $(p<0.05)$ decreased (from 18 to $13 \mathrm{mg} / \mathrm{g}$ ) at the fifth and sixth week and then increased at the seventh week after fruit set. The ash content of mesocarp decreased throughout the fruit development. By contrast, the ash content of endocarp increased from the first to the fifth week before a smoothly decrease at the end of maturation. Villanueva et al. [28] have shown that the ash content increases at the end of the development of melon fruit. These differences in ash content of the tibish melon fractions at various maturation stages may be explained by migration of different inorganic ions to the most active parts of the growing plant.
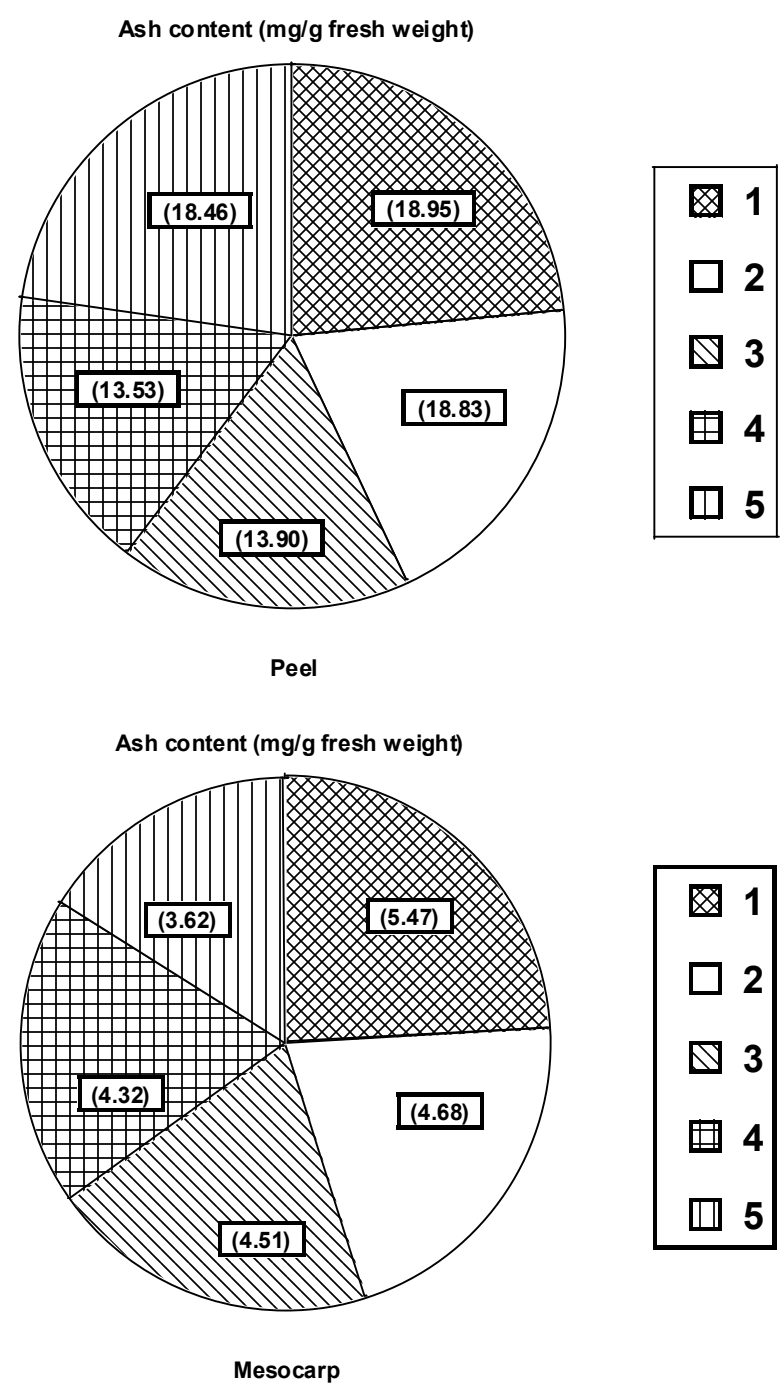

\section{Ash content (mg/g fresh weight)}

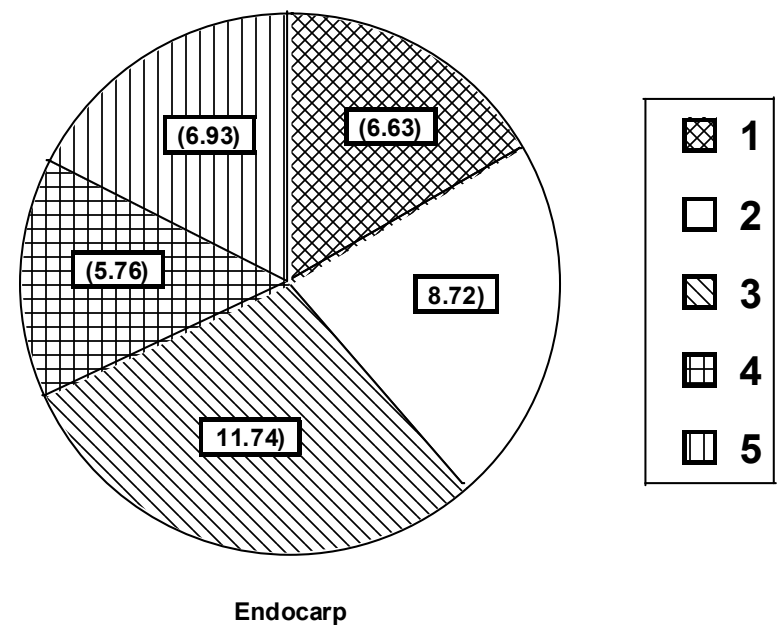

Figure 1. Variation of the ash content during maturity stage of Cucumus melo fruit fractions (peel, mesocarp and endocarp). The stages are determinate three (S1), four (S2), five (S3), six (S4) and seven (S5) weeks after fruit development. 


\subsubsection{Free Sugars, Total Carbohydrates and Starch Content of Melon}

Figure 2 shows that the soluble sugars content of melon fruit portions (peels, mesocarp and endocarp) varied significantly $(p<0.05)$ during the development and also from fraction to fraction $(0.6-2.5 \%$ fresh weight). In the early stage of the fruit development, mesocarp and endocarp were richer in soluble sugars than peels. By contrast, at full maturation stage, the soluble sugar content of peels increased while that of the other two portions decreased. Although slightly higher soluble sugar content (5-11\%) has been reported for Cantaloupe melon [31], we also noted significant decrease $(p<0.05)$ during tibish melon fruit ripening. Changes in the level of soluble sugars may be attributed to the metabolism of carbohydrates in the plant. In the early stage of maturation, green leaves synthesize sugars through photosynthesis. These sugars are distributed to all parts of the plant for the nutrient requirements. The decrease in soluble sugars content in the mesocarp and endocarp may be explained by their incorporation in storage polysaccharides such as starch or in fiber components such as cellulose during the fruit development $[34,35]$.
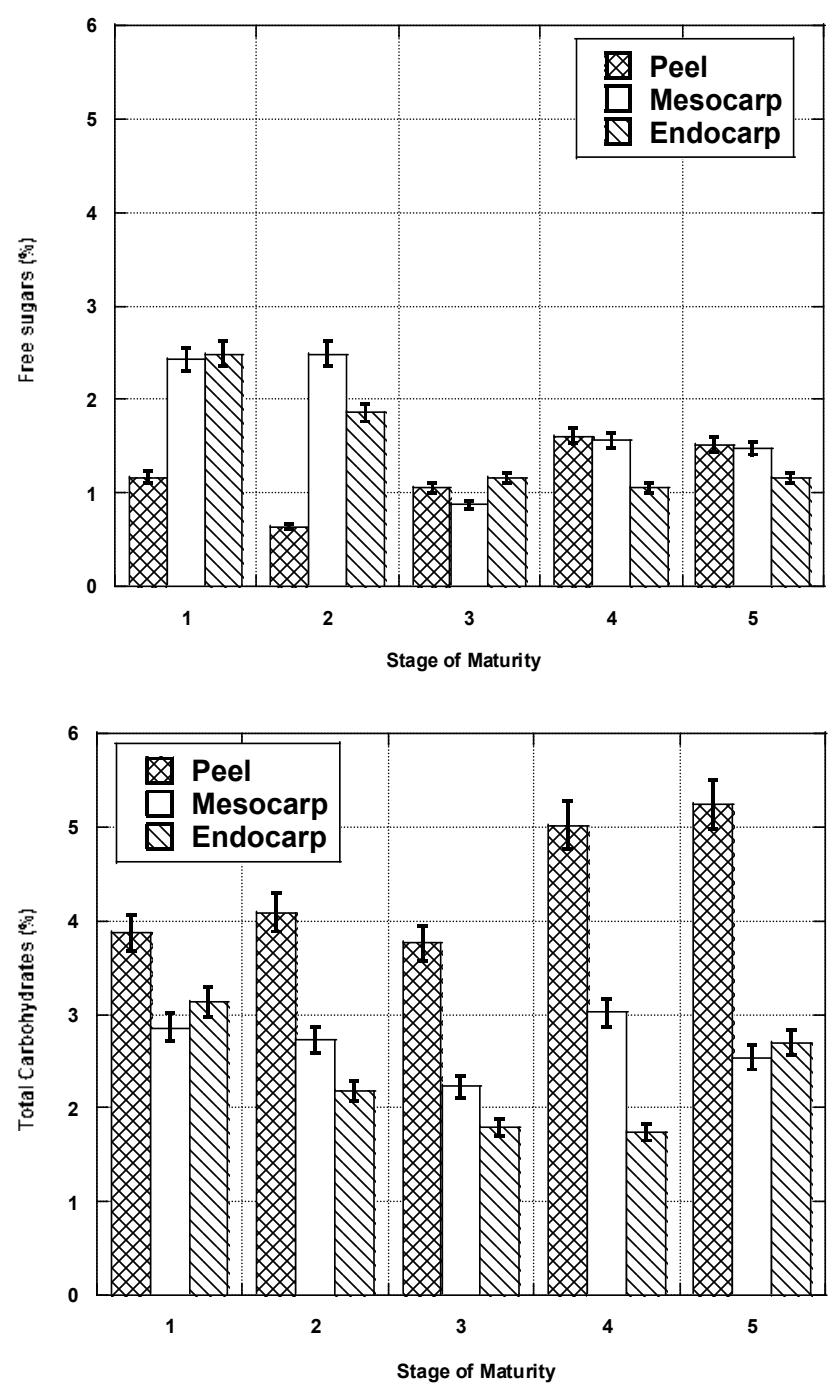

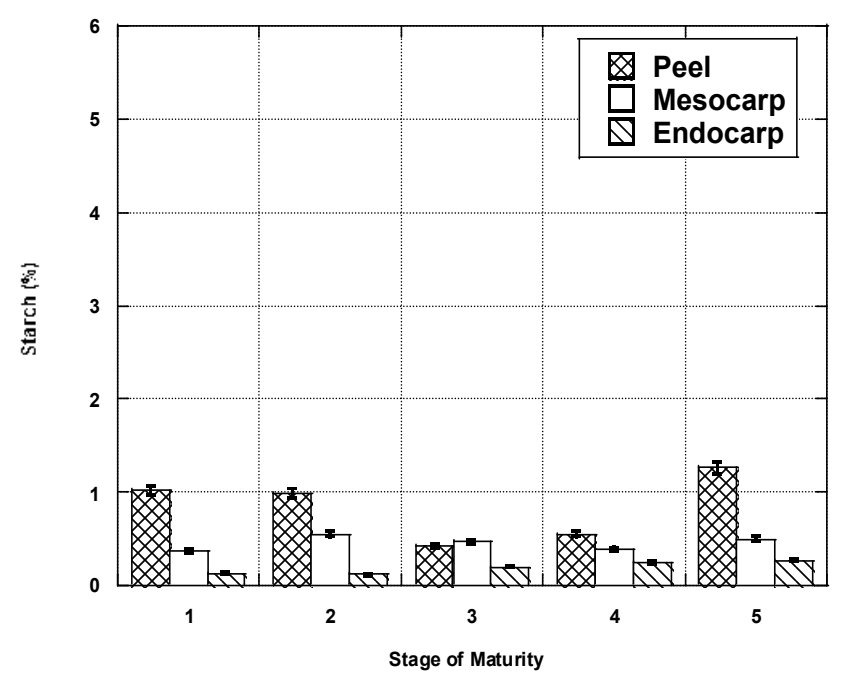

Figure 2. Changes in the free sugars, total carbohydrates and starch content during development of muskmelon (Cucumus melo, var tibish) fruit fractions (peel, mesocarp and endocarp). The stages are determinate three (S1), four (S2), five (S3), six (S4) and seven (S5) weeks after fruit development.

Significant changes $(p<0.05)$ in the total carbohydrates content were observed during the tibish melon fruit development (Figure 2). The level of carbohydrates content of peels increased from 3.75 to $5.23 \%$ (fresh weight) during maturation. In contrast, the total carbohydrates content decreased in the mesocarp and endocarp during the fruit development. Carbohydrates were more abundant in peels than in endocarp and mesocarp. Abundance of carbohydrates in peels may be attributed to an increase of the synthesis of cell wall polysaccharides (cellulose, pectins, and hemicelluloses). Nuñez-Palenius et al. [36] have shown that the total carbohydrates content increases during the development of Cantaloupe melon fruit.

The starch content of the different parts of the Tibish melon fruit (peels, mesocarp and endocarp) also varied significantly $(p<0.05)$ during the fruit development (Figure 2). In the peels, much higher starch content was observed at the early stage and at full maturation (from 0.54 to $1.25 \%$ ). The starch content of mesocarp increased from the third to fourth week after fruit set. It then decreased until the fifth week and increased again at the seventh week after fruit set. For endocarp, the starch content regularly increased from the early stage to full maturation of the fruit. This increase would be well related to the growth of the seeds (which are rich in starch) during the development $C$. melo fruit. The peels contained higher amounts of starch than the other portions of the fruit. The increase in starch content at the last stage of the fruit development could be due to the accumulation of carbohydrates in the storage tissues. De Souza et al. [37] have shown abundance of synthesized starchy polysaccharides in storage tissues of the fruit of Cucumis genus during maturation and their partial use during this process.

\subsubsection{Free Amino Acid, Crude Proteins and Total Lipids Content}

The crude lipids content of Tibish melon fruit varied from 
4.04 to $17.59 \mathrm{mg} / \mathrm{g}$ (Table 2) and depended on the portion and the stage of development. The peels had the highest lipids content and mesocarp the lowest. Unlike mesocarp, we observed that the lipids content of peel and endocarp increased during the fruit maturation. Similar results have been reported by Azhari et al. [12] for the Seinat melon endocarp seeds exhibiting a high fat content of $31.13 \%$.

Table 2. The influence of the maturity stage on the water absorption capacity (WAC), lipids and fibers content of Cucumus melo fruit fractions (peel, mesocarp and endocarp).

\begin{tabular}{|c|c|c|c|c|c|c|}
\hline \multirow{2}{*}{ Characteristics } & & \multicolumn{5}{|c|}{ Stage of maturity } \\
\hline & & S 1 & S 2 & S 3 & S 4 & S 5 \\
\hline \multirow{3}{*}{ Lipids $(\mathrm{mg} / \mathrm{g})$ * } & $P e$ & $9.99 \pm 0.11^{\mathrm{e}}$ & $12.59 \pm 0.24^{\mathrm{d}}$ & $13.71 \pm 0.21^{\mathrm{c}}$ & $15.97 \pm 0.21^{\mathrm{b}}$ & $17.59 \pm 0.41^{\mathrm{a}}$ \\
\hline & $M e$ & $5.43 \pm 0.25^{\mathrm{a}}$ & $5.71 \pm 0.20^{\mathrm{a}}$ & $4.64 \pm 0.21^{\mathrm{c}}$ & $4.27 \pm 0.21^{\mathrm{c}}$ & $5.02 \pm 0.12^{\mathrm{b}}$ \\
\hline & $E n$ & $5.65 \pm 0.23^{\mathrm{c}}$ & $6.80 \pm 0.26^{\mathrm{d}}$ & $9.10 \pm 0.31^{\mathrm{c}}$ & $11.52 \pm 0.43^{\mathrm{b}}$ & $15.10 \pm 0.23^{\mathrm{a}}$ \\
\hline \multirow{3}{*}{ Fibers $(\%) *$} & $P e$ & $4.62 \pm 0.16^{\mathrm{b}}$ & $3.76 \pm 0.09^{d}$ & $4.86 \pm 0.09^{\mathrm{b}}$ & $4.69 \pm 0.16^{\mathrm{b}}$ & $5.83 \pm 0.19^{\mathrm{a}}$ \\
\hline & $M e$ & $2.39 \pm 0.11^{\mathrm{a}}$ & $1.56 \pm 0.05^{\mathrm{b}}$ & $1.40 \pm 0.08^{\mathrm{c}}$ & $1.44 \pm 0.09^{\mathrm{bc}}$ & $1.59 \pm 0.08^{b}$ \\
\hline & $E n$ & $1.86 \pm 0.14^{\mathrm{ab}}$ & $1.39 \pm 0.09^{c}$ & $1.54 \pm 0.11^{\mathrm{c}}$ & $1.70 \pm 0.11^{\mathrm{b}}$ & $1.99 \pm 0.05^{\mathrm{a}}$ \\
\hline \multirow{3}{*}{ WAC $(\mathrm{mL} / \mathrm{g}) * *$} & $P e$ & $5.44 \pm 0.15^{\mathrm{b}}$ & $4.43 \pm 0.31^{\mathrm{c}}$ & $6.09 \pm 0.34^{\mathrm{a}}$ & $5.05 \pm 0.30^{\mathrm{b}}$ & $5.32 \pm 0.22^{\mathrm{b}}$ \\
\hline & $M e$ & $6.83 \pm 0.10^{\mathrm{a}}$ & $3.88 \pm 0.07^{b}$ & $3.86 \pm 0.23^{b}$ & $2.64 \pm 0.29^{c}$ & $2.48 \pm 0.05^{\mathrm{c}}$ \\
\hline & $E n$ & $4.04 \pm 0.20^{\mathrm{a}}$ & $2.31 \pm 0.06^{\mathrm{c}}$ & $2.40 \pm 0.18^{\mathrm{bc}}$ & $2.30 \pm 0.08^{c}$ & $2.54 \pm 0.06^{\mathrm{b}}$ \\
\hline
\end{tabular}

Mean values from triplicate measurements \pm standard deviation. Values in the same line followed by different superscripts are significantly different ( $<<0.05$ ). The stages are determinate three (S1), four (S2), five (S3), six (S4) and seven (S5) weeks after fruit development. Pe = Peel; Me = Mecocarp; En = Endocarp *Values are given on the fresh weight or ** dry weight basis
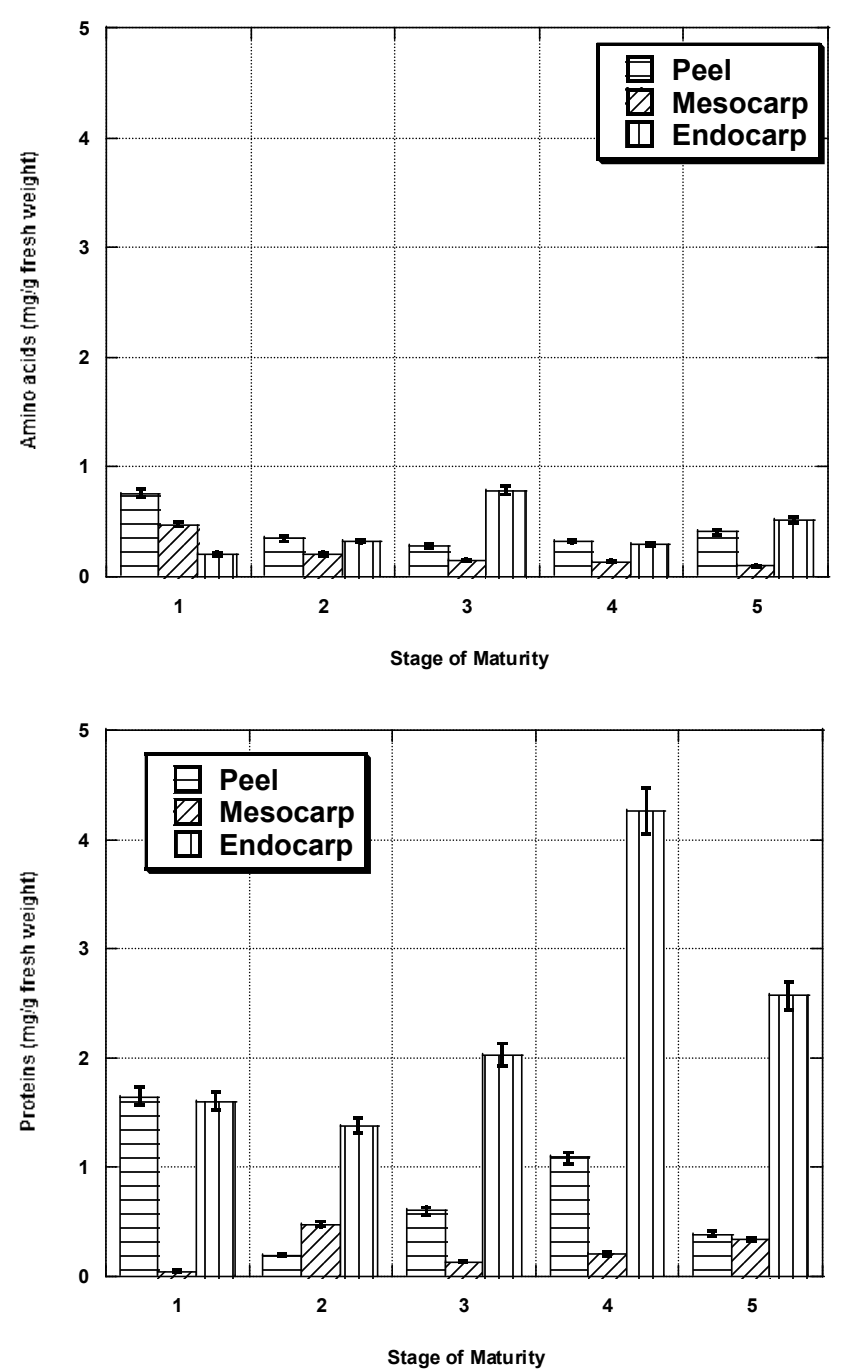

Figure 3. Influence of the growing stage on the free amino acids and total proteins content of muskmelon (Cucumus melo, var tibish) fruit fractions (peel, mesocarp and endocarp). The stages are determinate three (S1), four (S2), five (S3), six (S4) and seven (S5) weeks after fruit development.
During the development of Tibish melon fruit, variation occurred in the free amino acid content (Figure 3). At the early stages of development, the amino acid content of peels decreased, but this increased at full maturation stage. With the mesocarp, however, the free amino acid content decreased throughout maturation. The evolution trend of the amino acid content of the endocarp showed a peak at the third stage of the fruit development.

The peels exhibited the highest proteins content at the first stage of maturation (Figure 3), which decreased at the second and third stages before increasing slightly at the fourth stage. The proteins content of the endocarp was high $(1.7-4.2 \mathrm{mg} / \mathrm{g})$ and significantly $(p<0.05)$ increased during the fruit maturation. Compared to peels and endocarp, mesocarp had the lowest proteins content which increased at the full maturation stage. Rowan et al. [38] observed an increase in the proteins content of the melon fruit during maturation. Changes in the proteins content during the fruit development would be linked to various metabolic activities that occur during the plant growth [39, 40].

\subsubsection{Fiber Content and Hydration Properties}

The results of the fiber content of the different portions of Tibish melon fruit are shown in Table 2. The fiber content of peels decreased from 4.62 to $3.75 \%$ (fresh weight) between the third and the fourth week and then increased up to $5.83 \%$ at the seventh week after fruit set. Both the mesocarp and endocarp had low fiber content. The fiber content of mesocarp decreased throughout the fruit maturation, while that of the endocarp decreased at the early stage and increased at the full stage of maturation.

The water absorption capacity (WAC) of peels, mesocarp and endocarp varied significantly $(p<0.05)$ during the fruit maturation (Table 2). Peels exhibited the highest values of WAC, going up and down with a peak $(6.09 \mathrm{~g} / \mathrm{mL})$ at the fifth week after fruit set. As for the 
mesocarp and endocarp, their WAC decreased throughout the fruit maturation. The strong ability of the peels to absorb water may be explained by their high content in fiber components such as pectins which are endowed with great tendency to retain water [34]. In the cell wall, pectins are indeed involved in cellular thickening and cell growth [41]. Also, Koubala et al. [42] have suggested a positive correlation between the WAC and soluble fiber content of mango peels.

The swelling kinetics of peels, mesocarp and endocarp from Tibish melon fruit also varied with the fruit maturation stage (Figure 4). A rapid increase of swelling volume occurred from the first to the tenth (or twentieth) second, depending on the maturation stage or on the part of the fruit. For the endocarp and mesocarp, the swelling speed slowly increased and reached a constant value at about 40, 60 or 80 seconds. For the peels, the constant value was reached later, after 120 seconds. In the whole, the peels exhibited the highest swelling ability and endocarp the lowest.
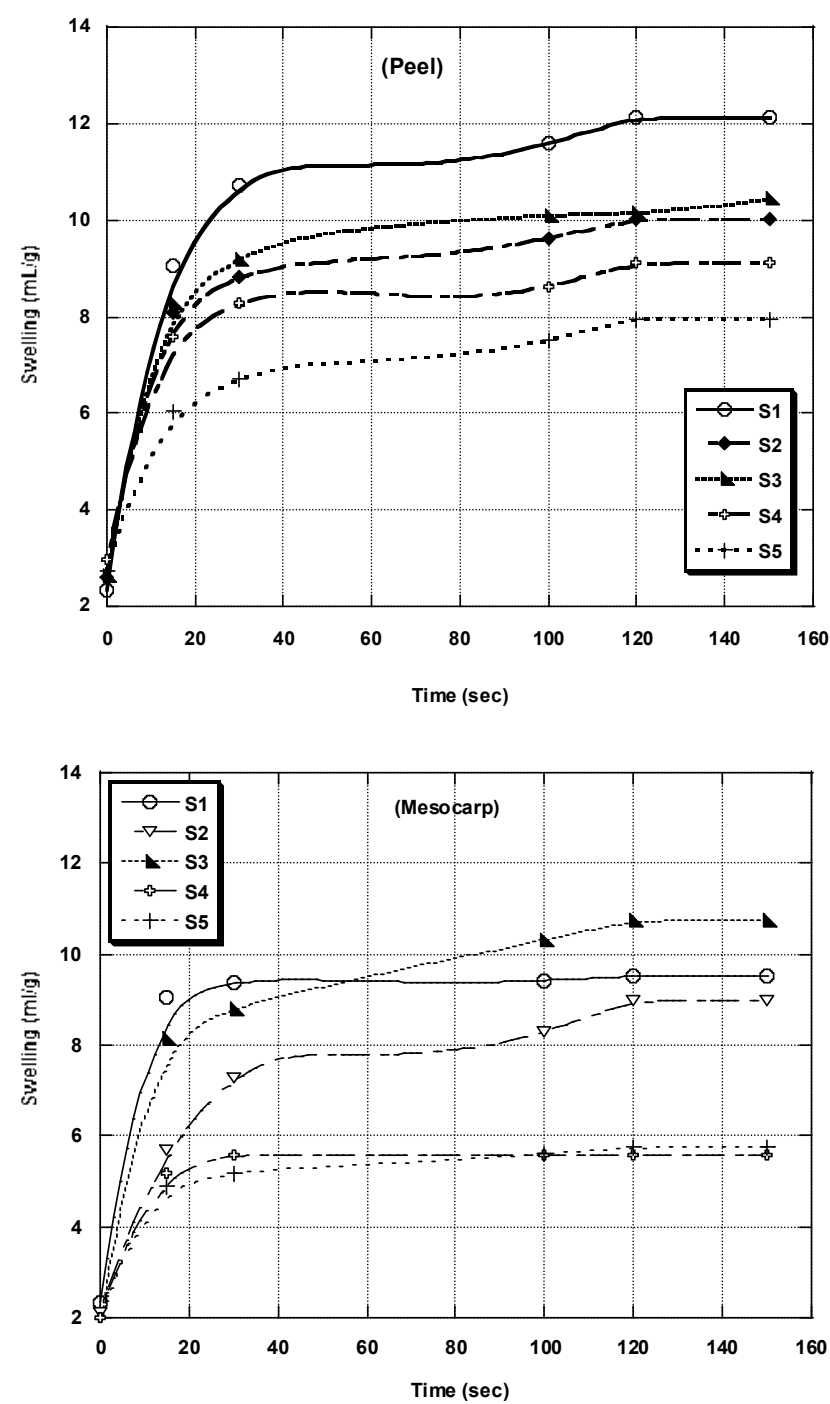

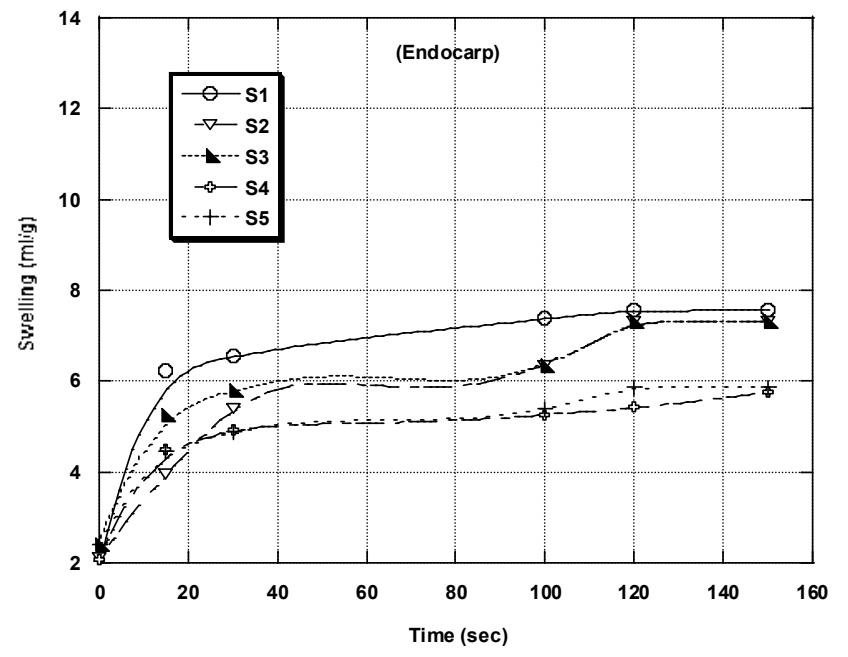

Figure 4. Effect of the growing stage on the swelling kinetics of muskmelon (Cucumus melo, var tibish) fruit fractions (peel, mesocarp and endocarp). The stages are determinate three (S1), four (S2), five (S3), six (S4) and seven (S5) weeks after fruit development.

\subsection{Evolution of Antioxydant Potential of Peels, Mesocarp and Endocarp from Tibish Melon Fruit During Growth}

\subsubsection{Total Phenolic Content}

The total phenolic content of peels, mesocarp and endocarp varied significantly $(p<0.05)$ during Tibish melon fruit development (Figure 5). This variation was more marked in the peels where more than $75 \%$ of decrease of phenolics occurred (12 to $1 \mathrm{mg} \mathrm{GAE} / \mathrm{g}$ ) from the third to the fifth week after fruit set. This rapid decrease could be due to the various changes in colour (from green to yellow) along the maturation process. Leja et al. [43] have observed significant changes in the total phenolic content, from 0.18 to $2.45 \mathrm{mg} / \mathrm{g}$, with white, yellow, orange red and purple carrot roots. The total phenolic content of mesocarp and endocarp was rather low (1-3 mg GAE / g) throughout fruit development. Hajar et al. [44] have also reported a total phenolic content of $2.85 \mathrm{mg}$ GAE / g for Cantaloupe melon fruit seeds. At the early stage of the fruit maturation, the peels were five to six times richer in phenolic compounds than the mesocarp and endocarp.

\subsubsection{Ferric Reducing Antioxidant Potential (FRAP)}

Figure 5 illustrates the total antioxidant capacity as FRAP of the different Tibish melon fruit samples. The FRAP of peels, mesocarp and endocarp varied during the fruit development. Whatever the stage of development, the FRAP was higher with peels (3.50-7.08 micromole equivalent Trolox / g fresh weight). While the FRAP of the peels increased with the different stages of development, that of the mesocarp decreased. Zozio et al. [45] have also shown that the antioxidant activity of jujube fruit decreased in the course of ripening. With the endocarp, which exhibited the lowest FRAP, no significant variation was found throughout the fruit development. The evolution of the total antioxidant capacity was not found to be correlated with the total phenolic content of each fraction of the fruit. This suggested that 
macromolecules with antioxidant activity might not only be phenolic compounds. Tibish melon would possess other

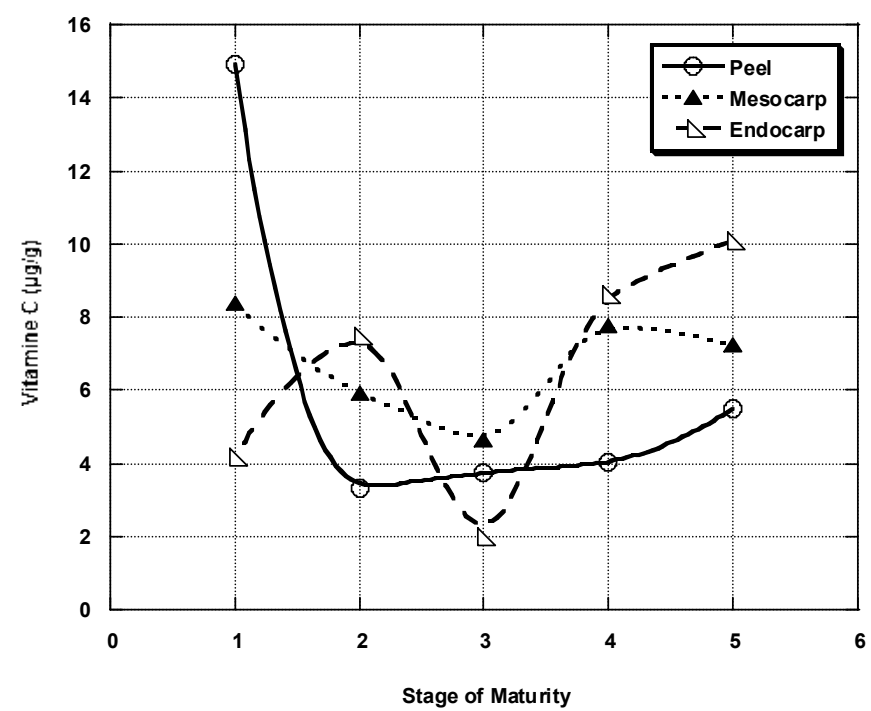

(FRAP)

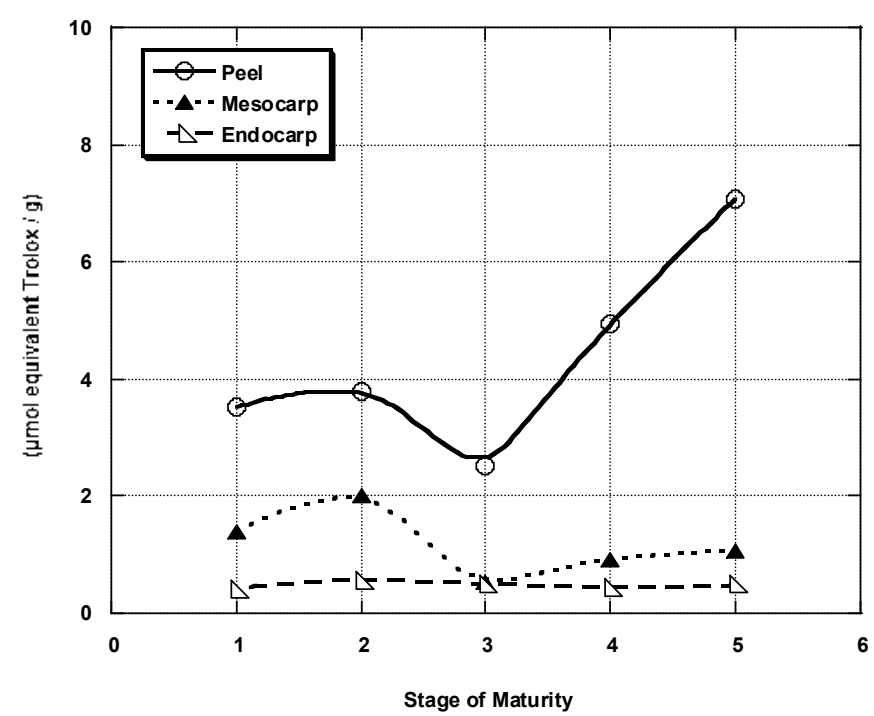

antioxidant compounds such as vitamin $\mathrm{C}$, methionine and carotenoids [46].

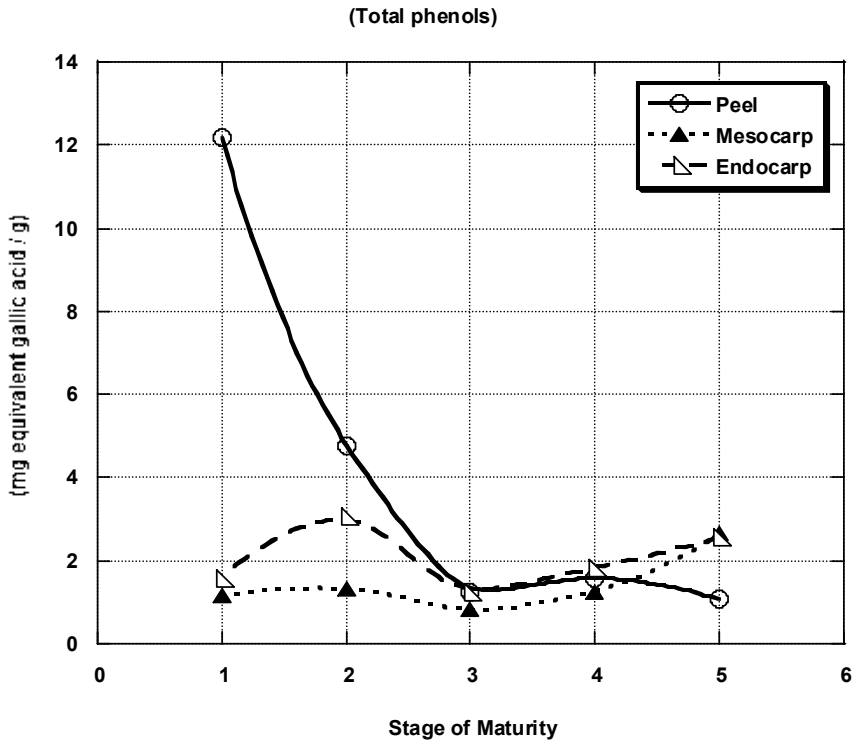

(DPPH Radical-Scavenging)

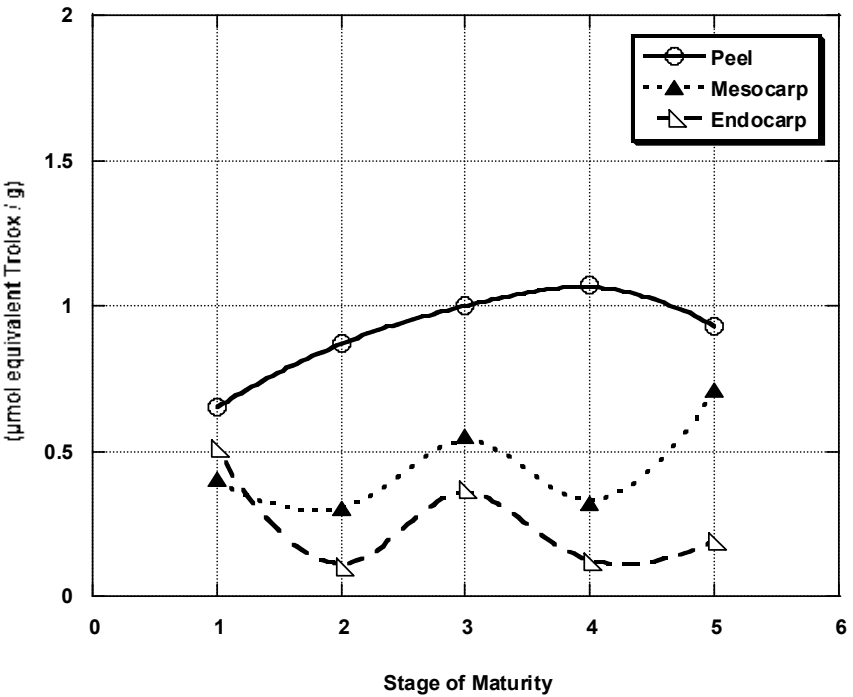

Figure 5. Changes in vitamin C content, phenols composition, total antioxidant potential (FRAP) and DPPH radical-scavenging during development of Cucumus melo fruit fractions (peel, mesocarp and endocarp). The stages are determinate three (S1), four (S2), five (S3), six (S4) and seven (S5) weeks after fruit development.

\subsubsection{Vitamin C Content}

Figure 5 presents the results of the vitamin $\mathrm{C}$ content. The vitamin $\mathrm{C}$ content of Tibish melon fruit depended on the part of the fruit and the development stage $(2-15 \mu \mathrm{g}$ equivalent ascorbic acid / $\mathrm{g}$ fresh weight). At the early stage of maturation, the peels exhibited the highest vitamin $\mathrm{C}$ content. However, from stage 2 to stage 5 (full maturation), the endocarp and mesocarp appeared richer in vitamin $\mathrm{C}$ than peels. The vitamin $\mathrm{C}$ content of mesocarp and endocarp evolved in zigzag shape during the fruit development (Figure 5). The vitamin $\mathrm{C}$ content of the Tibish melon mesocarp is lower than that of Ravi Muskmelon (33 mg / g) reported by Parveen et al. [30]. The recommended dietary intake of vitamin $\mathrm{C}$ is $60-90 \mathrm{mg} / \mathrm{day}$ for children [47]. According to
Lester et al. [3], muskmelon fruit is one of the most ten fruits consumed in United States and one serving size of it represents $131 \%$ of recommended daily dietary allowance in vitamin C. Likewise, Tibish melon fruit may be recommended as a source of vitamin $\mathrm{C}$ for human diet. The decrease of the vitamin $C$ content may be a result of ascorbic acid oxidation in the presence of transition metals such as iron [48]. Generally, the decrease in vitamin C content of fruit is related to the degradation of the fruit tissues at full maturation [49].

\subsubsection{DPPH Radical-Scavenging Activity}

The antioxidant activity, as DPPH-radical scavenging activity, of peels, mesocarp and endocarp of Tibish melon 
fruit significantly $(p<0.05)$ varied during the fruit development (Figure 5). In peels, it increased with the maturation process $(0.64-1.07 \mu \mathrm{mol}$ Trolox equivalent $/ \mathrm{g}$ fresh weight). Whatever the stage of development, the mesocarp and endocarp exhibited low DPPH-radical scavenging activity $(0.11-0.71 \mu \mathrm{mol}$ Trolox equivalent $/ \mathrm{g})$ which went up and down with peaks at the early stage of the fruit maturation, mid maturation and at full maturation stage. These variations may be related to the synthesis or degradation of vitamin $\mathrm{C}$, carotenoids and phenolic compounds such as flavonols and anthocyanins. Leja et al. [43] have found correlation between the anthocyanins content of carrot root and its antiradical activity

\section{Conclusion}

This present work reports on some changes in morphological and physicochemical parameters of the tibish melon fruit during development. From the third to the seventh week after fruit set, the chemical and physicochemical parameters were found to vary significantly $(p<0.05)$ during the fruit development. The morphological characteristics of the fruit of Cucumis melo reached maximum values at full maturation stage (stage 5), corresponding to the seventh week after fruit set. At this last stage, the polar and equatorial diameter of tibish melon fruit were approximately $13.83 \mathrm{~cm}$ and $8.07 \mathrm{~cm}$, respectively. The physicochemical and antioxidant properties of tibish melon fruit peels, mesocarp and endocarp appeared to be significantly different and not to evolve in the same way during the fruit development. The mesocarp exhibited higher antioxidant and radical-scavenging capacities than the endocarp. Depending on the nutrient requirements, peels, mesocarp or endocarp at a particular stage of Cucumis melo fruit development will be required. A mass consumption of Tibish muskmelon fruit in the far north region of Cameroon will well-balance diets contributing to the prevention of malnutrition disorders.

\section{Acknowledgments}

We are grateful to the IRAD (Agriculture Research for Development Institute) of Maroua (Cameroon) for describing and naming of the local experimental fruit melon (Cucumis melo var. Tibish).

\section{References}

[1] Judd W. S., Campbell C. S., Kellogg E. A., Stevens P. F. \& Donoghue M. J. (2002). Sistemática de Plantas: A Phylogenetic Approach, $2^{\text {nd }}$ ed. (Cucurbitales). Sinauer Associates, Sunderland, Massachusetts, Wallingford, UK, 576p.

[2] Matthews M. L. \& Endress P. K. (2004). Estructuras florales y sistemática comparada en Cucurbitales (Corynocarpaceae, Coriariaceae, Tetramelaceae, Datiscaceae, Begoniaceae, Cucurbitaceae, Anisophylleaceae), Botanical Journal of Linnean Society, 145(2), 129-185.
[3] Lester R. N., Jaeger P. M. L., Bleijendaal-Spierings B. H. M., Bleijendaal H. P. O. \& Holloway H. L. O. (1990). African eggplants: a review of collecting in West Africa, Plant Genetic Resources Newsletter, (81/82), 17-26.

[4] Haldhar S. M., Bhargava R., Choudhary B. R., Pal G. \& Kumar S. (2013). Allelochemical resistance traits of muskmelon (Cucumis melo) against the fruit fly (Bactrocera cucurbitae) in a hot arid region of India, Phytoparasitica, 41(4), 473-481.

[5] Goodwin J. S. \& Brodwick M. (1995). Diet, aging and cancer, Clinics in Geriatric Medicine 11, 577-589.

[6] Rimm E. B., Klatsky A., Grobbee D. \& Stampfer M. J. (1996). Review of moderate alcohol consumption and reduced risk of coronary heart disease: Is the effect due to beer, wine, or spirits? British Medical Journal, 312, 731-736.

[7] Pitrat M. (2008). Melon, In: Prohens J., Nuez F. (Eds.), Vegetables 1 (pp. 283-315) USA: Springer.

[8] Shalit M., Katzir N., Tadmor Y., Larkov O., Burger Y., Shalekhet F., Lastochkin E., Ravid U., Amar O., Edelsten M. \& Lewinsolhn E. (2001). Acetyl CoA: alcohol acetyl transferase activity and aroma formation in ripening melon fruits, Journal Agricultural and Food Chemistry, 49, 794-799.

[9] Yuan D. B., Yang X. Q., Tang C. H., Zheng Z. X., Min W., Ahmad I. \& Yin S. W. (2009). Physicochemical and functional properties of acidic and basic polypeptides of soy glycinin, Food Research International, 42, 700-706.

[10] Adams C. F. \& Richardson M. (1981). Nutritive value of foods, USDA home and Garden Bul. 72. Government Printing Office, Washington D. C.

[11] Al-Khalifa A. S. (1996). Physicochemical characteristics, fatty acid composition and lipoxygenase activity of crude pumpkin and melon seed oils, Journal of Agricultural and Food Chemistry, 44(4), 964-966.

[12] Azhari S., Xu Y. S., Q. X. Jiang \& W. S. Xia (2014). Physochemical properties and chemical composition of Seinat (Cucumus melo var Tibish) seeds oil and its antioxidant activity, Gracas Aceites, 65(1), e008.

[13] AOAC. (1990). Official methods of analysis of AOAC International (15th Ed). In: Herwitz W. (Ed.), Association of Official Analytical Chemists. Washington DC, 132 pp. 125126.

[14] Kansci G., Koubala B. B. \& Mbome L. I. (2003). Effect of ripening on the composition and the suitability for jam processing of different varieties of mango (Mangifera indica), African Journal of Biotechnology, 2 (9) 301-306.

[15] Michel M. C. (1968). Dosage des acides aminés et amines par la ninhydrine. Amélioration pratique, Annal de Biologie Animale, Biochimie, Biophysique, 8, 557-563.

[16] Devani M. B., Shishoo C. J., Shal S. A. \& Suhagia B. N. (1989). Spectrophotometric method for microdetermination of nitrogen in Kjedahl digest, Journal of the Association of Official Agricultural Chemists, 72(6), 953-956.

[17] AFNOR (Association Française pour la Normalisation) (1984). Produits alimentaires: directives générales pour le dosage de l'azote avec minéralisation selon la méthode de kjedahl. Dans: Godon, Pineau (Eds), Guide Pratique des Céréales, Apria, France, 4 263-266. 
[18] Tollier M. T. \& Robin J. P. (1979). Adaptation de la méthode à l'orcinol sulfurique au dosage automatique des glucides neuters totaux. Conditions d'adaptation aux extraits d'origine végétale, Annales de Technologie Agricole, 28, 1-15.

[19] Koubala B. B., Mbome L. I., Kansci G., Mbiapo F. T., Crépeau M. -J. \& Thibault J. -F. (2008). Physicochemical properties of pectins from ambarella peels (Spondias cytherea) obtained using different extraction conditions, Food Chemistry, 106, 1202-1207.

[20] Jarvis C. E. \& Walker J. R. L. (1993). Stimultaneous, rapid, spectrophotemetric determination of total starch, amylolose and amylopectin, Journal of the Science Food and Agriculture, 63, 53-57.

[21] Kuniak L. \& Marchessault R. H. (1972). Study of crosslinking reaction between epichlorhydrine and starch, StarchStarke, 4, 110-116.

[22] Barakat M. Z. \& Abdalla A. (1965). The Ascorbic Acid Content of Edible Liver, Journal of Food Science, 30(2), 185187.

[23] Singleton V. L., Orthofer R. \& Lamuela-Raventos (1999). Analysis of total phenols and other oxidation substrates and antioxidants by means of Folin-Ciocalteu reagent, Methods in Enzymology, 299, 152-178.

[24] Benzie I. F. F. \& Strain J. J. (1996). The ferric reducing ability of plasma (FRAP) as a measure of "antioxidant power": the FRAP assay, Analytical Biochemistry, 239, 70-76.

[25] Sun T., Tang J. \& Powers J. R. (2005). Effect of pectolytic enzyme preparations on the phenolic composition and antioxydant activiy of asparagus juice, Journal Agricultural and Food Chemistry, 113, 964-969.

[26] Ahmed O. K. (2009). Evaluation of Objective Maturity Indices for Muskmelon (Cucumis melo) cv."Galia", Journal of King Abdulazi University-Science, 21 (2), 317-326.

[27] Crane J. C. (1964). Growth substances in fruit setting and development, Annual Review of Plant Physiology, 15, 303326.

[28] Villanueva M. J., Tenorio M. D., Esteban M. A. \& Mendoza M. C. (2004). Compositional changes during ripening of two cultivars of muskmelon fruits, Food Chemistry, 87, 179-185.

[29] Bernadac A., Jean-Baptiste I., Bertoni G. \& Morard P. (1996). Changes in calcium contents during melon (Cucumis melo L.) fruit development, Scientia Horticulturae, 66(3), 181-189.

[30] Parveen S., Ali M. A., Asghar M., Khan A. R. \& Salam A. (2012). Physico-chemical changes in muskmelon (Cucumis melo L.) as affected by harvest maturity stage, Journal of Agricultural Research, 50(2), 249-250.

[31] Beaulieu J. C. \& Lea J. M. (2007). Quality changes in cantaloupe during growth, maturation, and in stored fresh-cut cubes prepared from fruit harvested at various maturities, Journal of American Society for Horticultural Science, 132(5), 720-728.

[32] Bianchi T., Guerrero L., Gratacós-Cubarsí M., Claret A., Argyris J., Gracia-Mas J. \& Hortós M. (2016). Textural properties of different melon (Cucumis melo L.) fruit types: Sensory and physical-chemical evaluation. Scientia Horticulturae, 201, 46-56.
[33] Ozawa T., Lilley T. H. \& Haslam E. (1987). Polyphenol interactions: astringency and the loss of astringency on ripening fruit, Phytochemistry, 26, 2937-2942.

[34] Cheftel J. C. \& Cheftel H. (1992). Introduction à la Biochimie et à la Technologie des aliments, Technique et Documentation Ed., Paris 1, 147-241.

[35] Moneruzzaman K. M., Hossain A. B. M. S., Sani W. \& Saifuddin M. (2008). Effect of stages of maturity and ripening conditions on the physical characteristics of tomato, American Journal of Biochemistry and Biotechnology, 4(4), 329-335.

[36] Nuñez-Palenius H. G., Gomez-Lim M. \& Ochoa-Alejo N. (2008). Melon Fruits: Genetic Diversity, Physiology, and Biotechnology Features, Critical Reviews in Biotechnology, 28, 13-55.

[37] De Souza P. A., Simões A. D. N., Puiatti M. \& Junior J. G. (2013). Da Silva Vieira M. R. Carbohydrate metabolism and quality of fruits from the Cucumis genus, Academia Journal of Agricultural Research, 1(7), 101-105.

[38] Rowan K. S., Mcglasson W. B. \& Pratt H. K. (1969). Changes in Adenosine Pyrophosphates in Cantaloupe Fruit Ripening Normally and after Treatment with Ethylene, Journal of Experimental Botany, 20, 145-155.

[39] Abu-Goukh A. -B. A., Baraka Al F. M. \& Elballa M. M. A. (2011). Physico-chemical changes during growth and development of 'Galia' cantaloupes. II. Chemical changes, Agriculture and Biological Journal of North America, 2(6), 952-963.

[40] Wills R., McGlasson B., Graham D. \& Joyce D. (1998). Postharvest: An introduction to the physiology and handling of fruit, vegetables and ornamentals, Wallingford: $\mathrm{CAB}$ International, $262 \mathrm{p}$.

[41] Mc Cartney L. \& Knox J. P. (2002). Regulation of pectic polysaccharide domains in relation to cell development and cell properties in the pea testa, Journal of Experimental Botany, 533 (369), 707- 713.

[42] Koubala B. B., Kansci G., Garnier C., Thibault J. -F. \& Ralet M. -C. (2013). Physicochemical properties of dietary fibres prepared from ambarella (Spondias cytherea) and mango (Mangifera indica) peels, Food and Bioprocess Technology, 6(2), 591-597.

[43] Leja M., Kamińska I., Kramer M., Maksylewicz-Kaul A., Kammerer D., Carle R. \& Baranski R. (2013). The Content of Phenolic Compounds and Radical Scavenging Activity Varies with Carrot Origin and Root Color, Plant Foods for Human Nutrition, 68, 163-170.

[44] Zozio S., Servent A., Cazal G., Mbéquié-A-Mbéquié D., Ravion S., Pallet D. \& Abel H. (2013). Changes in antioxidant activity during the ripening of Jujube (Ziziphus mauritiana Lamk), Food Chemistry, 1(150), 448-456.

[45] Abdou B. A., Njintang Y. N., Scher J. \& Mbofung C. M. (2010). Phenolic compounds and radical scavenging potentials of twenty Cameroonian spices. Agriculture and Biological Journal of North America, 1(3), 213-224.

[46] EFSA (2013). Panel on Dietetic Products, Nutrition and Allergies: Scientific Opinion on Dietary Reference Values for vitamin C, European Food Safety Authority Journal, 11(11), 3418, 68 pp. doi:10.2903/j.efsa.2013.3418. 
[47] Halliwell B. (1994). Free radicals, antioxidants, and human disease: curiosity, cause, or consequence? The Lancet, 344, 721-724.

[48] Kalt W. (2005). Effects of production and processing factors on major fruit and vegetable antioxidants. Journal of Food Science, 70, 11-19.
[49] Hajar I. I., Kim W. C., Abdalbasit A. M. \& Maznah I. (2009). Phenolic content and antioxidant activity of cantaloupe (Cucumis melo) methanolic extract, Food Chemistry, 119(2), 643-647. 